\title{
ACTIVITATEA ENZIMELOR ANTIOXIDANTE LA PĂR ÎN FUNCȚIE DE ACT,IUNEA SBA REGLALG ȘI A MICROELEMENTELOR
}

\author{
Popovici A., Bujoreanu N. \\ Institutul de Genetică, Fiziologie și Protecție a Plantelor, \\ bujoreanu.apple@gmailcom
}

\begin{abstract}
According to the data obtained from the research we find that the natural growth regulator Reglalg and Reglalg in combination with trace elements have had a beneficial effect in regulating the activity of enzymes peroxidase and polyphenol oxidase which play an important role in vital processes of resistance and increased plant productivity.The redox processes in the leaves of the tardive Noiabriscaia and Socrovisce pear varieties depended on the metabolic processes in the
\end{abstract}


development of plants in ontogenesis, the stages of plant development, the action of their living conditions, the amount of oxidative substances that formed in plant cells under the action of high temperatures, give the particularities of varieties as well as the action of SBA Reglalg and microelements used to treat trees.Thus, with the modification of peroxidase and polyphenol oxidase activity during phenophases, we find their participation in metabolic processes that correlate with the function of resistance and adaptation of plants to unfavorable environmental conditions and consequently crop formation and fruit quality.

Keywords: Pear trees enzymes peroxidase and polyphenol oxidase, natural growth regulators Reglalg, microelements.

\section{Introducere}

Un rol important în procesele de oxido-reducere la plantele de cultură, inclusiv și la pomii fructiferi, le aparține enzimelor antioxidante peroxidaza și polifenoloxidaza. Acestea contribuie la modificarea calitativă a schimbului de substanţe pe parcursul ontogenezei plantelor, posedând în același timp o însemnătate deosebită în asigurarea adaptării lor la modificările permanente, inclusiv nefavorabile, ale condiţiilor mediului înconjurător $[1,3,9]$.

Odată cu schimbarea condiţiilor de creștere a plantelor de cultură se modifică activitatea şi direcţia de acţiune a enzimelor antioxidante. Ca răspuns la reacţiile de stres a acţiunii factorilor nefavorabili, enzimele antioxidative sunt implicate în inactivarea radicalilor oxigenaţi [4,5]. În condiţiile optime de vegetaţie, datorită funcţionării sistemelor de protecţie antioxidativă, în celule se păstrează un echilibru dinamic al proceselor de formare şi de lichidare a formelor active de oxigen. Nivelul intracelular al enzimelor antioxidative este determinat genetic şi, de regulă, activează în complex. Astfel, sistemele fermentative se specializează în scopul realizării diferitor etape de reducere a oxigenului $[9,10,11]$. Enzimele peroxidaza şi polifenoloxidaza catalizează dehidratarea diferitor substraturi (fenoli, amine, flavonoizi, acizi aminici ş.a.) [2, 8]. Peroxidaza îndeplineşte funcţii multiple în ţesuturile vegetale referitoare la procesele vitale importante:creştere, lignificare, respiraţie, rezistenţă Ş.a.

Reieșind din cele expuse, scopul cercetărilor constă în aprecierea activității enzimelor antioxidante (peroxidaza şi polifenoloxidaza) în rezultatul aplicării microelementelor B, Zn, Mn, Mo și reglatorului de creștere Reglalg pe durata perioadei de vegetaţie la pomii de păr.

\section{Materiale și metode}

Cercetările științifice au fost efectuate la pomii de păr crescuți în lizimetrele complexului vegetal al institutului. În studiu au fost incluse soiurile Socrovişce (de toamnă) și Noiabriscaia (de iarnă). Pomii de păr au fost trataţi foliar cu soluţia apoasă a reglatorului de creştere Reglalg (0,05\%) și microelementelor B, Zn, Mn, Mo (0,1\%), aplicate separat și/sau în complex, după 10-12 zile de la înflorire și în faza creșterii intensive a lăstarilor. Pentru analize au fost colectate frunze la fiecare două săptămâni, selectate de la pomii tratați pe parcursul perioadei de vegetație conform variantelor: Reglalg (i); Reglalg+microelemente (ii); microelemente (iii). În calitate de martor au servit pomii tratați cu apă. Activitatea enzimelor peroxidaza (PO) și polifenoloxidaza (PFO) a fost determinată conform metodelor standard [6, 7].

\section{Rezultate și discuții}

În rezultatul cercetărilor efectuate s-a constatat, că în fenofaza de creștere intensivă a lăstarilor activitatea enzimei peroxidaza a sporit în frunzele ambelor soiuri, datorită activizării proceselor metabolice în pomii de păr. La finele acestei fenofaze activitatea peroxidazei în frunzele soiurilor de păr cercetate a diminuat cu 31-39\% la soiul Noiabriscaia, și cu 49-55\% 
la soiul Socrovişce, în dependență de varianta experimentală (fig. 1). În fenofaza de încetinire şi încetare a creșterii vegetative a lăstarilor, activitatea peroxidazei sporește, alcătuind la pomii soiului de toamnă Socrovişce o creștere în dependență de varianta experimentală cu 23-41\%, iar la cel de iarnă Noiabriscaia cu $76-86 \%$ din lungimea totală a lăstarilor anuali. Această majorare se datorează în mare măsură proceselor vitale ce au decurs în pomii de păr (creșterea intensivă în volum şi masă a fructelor, acumularea substanţelor de rezervă şi lignificarea lăstarilor) şi de condiţiile de dezvoltare ale lor. Menționăm că, valorile maxime ale densității optice a peroxidazei s-au atestat la începutul lunii septembrie (fenofaza de maturare), constituind o sporire de 1,4-1,8 ori comparativ cu începutul perioadei de vegetaţie, care probabil a fost condiționată și de acțiunea temperaturilor ridicate la acel moment și corespunde coacerii fructelor și maturării lăstarilor. La soiul Socrovişce diminuarea activităţii peroxidazei a fost urmată de o creștere treptată până la începutul lunii septembrie. În acest timp activitatea peroxidazei a fost de 1,14- 1,23 ori mai înaltă în raport cu cea depistată la începutul perioadei de vegetaţie, având aceleaşi cauze de influenţă asupra ei ca şi la soiul Noiabriscaia.
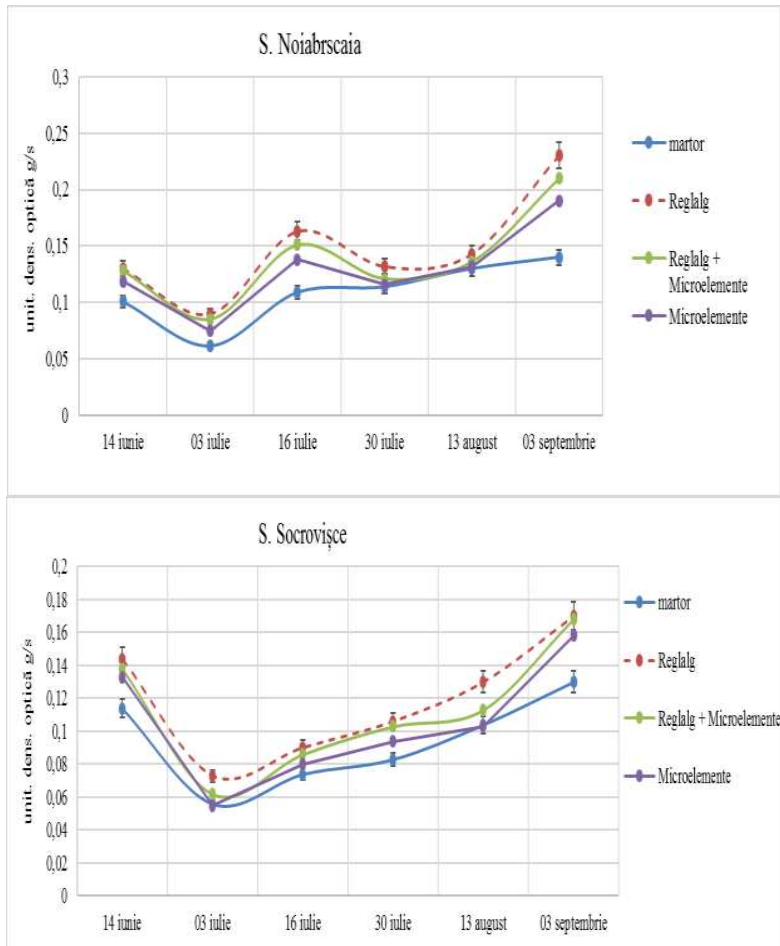

Figura 1. Dinamica modificării activității peroxidazei în frunzele pomilor de păr în dependență de aplicarea tratamentelor cu Reglalg și microelemente

Astfel, constatăm că activitatea peroxidazei s-a modificat la aceste soiuri în dependenţă de particularitățile biologice ale soiului, intensitatea proceselor fiziologice și biochimice ce au derulat în anumite fenofaze de creștere, condițiile de dezvoltare ale pomilor fructiferi, precum şi de tratamentele aplicate cu Reglalg şi microelemente. În toate variantele experimentale activitatea peroxidazei în frunzele pomilor de păr a fost mai sporită în raport cu cea a martorului. În cazul tratării pomilor cu Reglalg, în dependență de fenofaza de creștere şi condiţiile mediului înconjurător, activitatea acesteia s-a majorat în raport cu varianta martor 
cu 9-64\% la soiul Noiabriscaia și respectiv - 22-32\% la soiul Socrovişce. În varianta aplicării complexe Reglalg + microelemente la s. Noiabriscaia activitatea enzimei a fost cu 4,0-50,0\%, iar la s. Socrovişce cu 9,0-29,0\% mai înaltă în raport cu varianta martor. În lotul pomilor tratați cu microelemente activitatea peroxidazei a constituit valori majorate: la s. Noiabriscaia cu 4-36\%, iar la s. Socroviş̧ce respectiv, cu 5-26\%, în raport cu martorul.

Astfel, cel mai mult activitatea peroxidazei a fost influenţată în urma aplicării tratamentelor cu SBA Reglalg și SBA Reglalg + m.e. decât în celelalte două variante. Deosebiri în activitatea enzimei peroxidaza sunt înregistrate şi în dependență de particularităţile fiziologice ale soiurilor de păr luate în studiu. În frunzele soiului de iarnă Noiabriscaia, activitatea enzimei peroxidaza a fost mai înaltă decât la soiul de toamnă Socrovişce, cu excepţia fenofazei de creştere intensivă a lăstarilor.

Activitatea polifenoloxidazei în frunzele soiurilor cercetate, pe durata perioadei fenofazei de creştere intensivă a lăstarilor a fost înaltă, iar spre finele acesteia a avut loc o descreştere semnificativă. La s. Noiabriscaia, în dependență de variantele tratamentelor diminuarea activității acestei enzime a variat între $25-44 \%$, iar la s. Socrovişce, respectiv cu $41-50 \%$. Pe durata fenofazei de încetinire și încetare a creșterii lăstarilor la pomii s. Noiabriscaia, a fost înregistrată o creştere a activităţii polifenoloxidazei cu 12-15\%, urmată de o descreştere nesemnificativă, ce s-a menţinut până la începutul lunii septembrie (fig. 2).

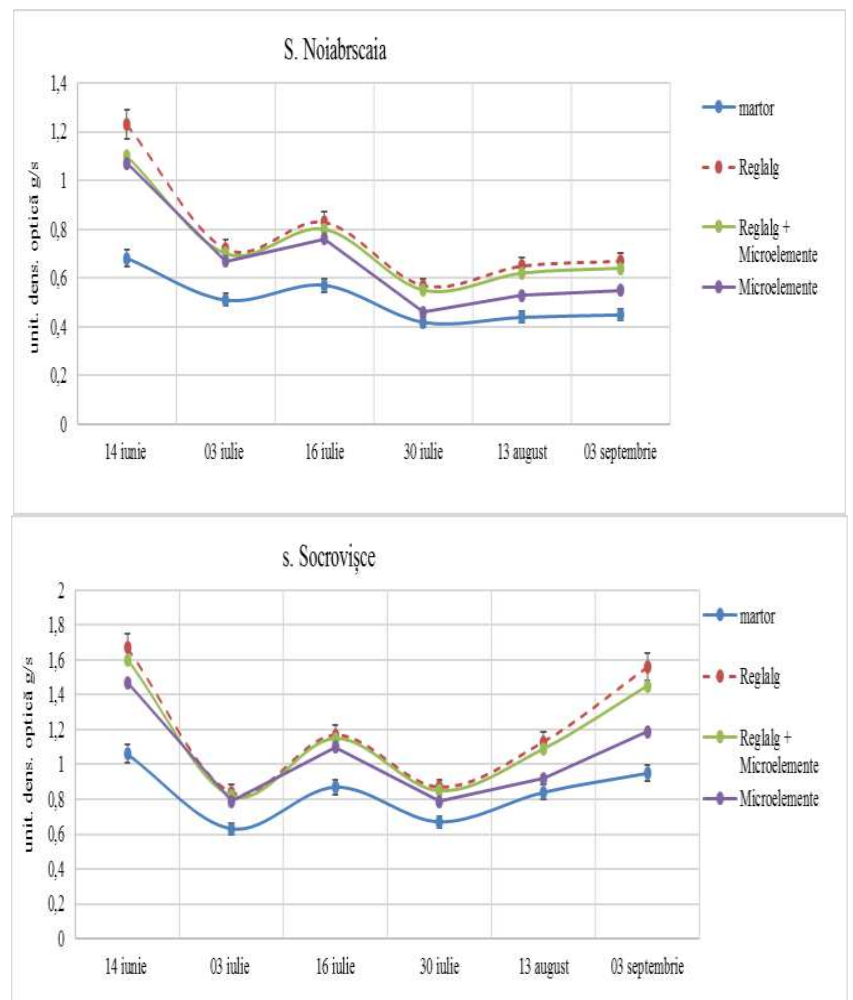

Figura 2. Dinamica modificării activității polifenoloxidazei în frunzele pomilor de păr în dependență de aplicarea tratamentelor cu Reglalg și microelemente

La s. Socrovişce activitatea polifenoloxidazei a sporit cu $38-40 \%$, urmată de o modificare a activităţii acesteia, fiind mai înaltă la începutul lunii septembrie, însă neatingând valorile acesteia atestate în fenofaza de creştere intensivă a lăstarilor. 
Conform rezultatelor obținute putem menționa, că activitatea polifenoloxidazei a depins de particularităţile biologice ale soiurilor cercetate, rezistența lor la condițiile mediului înconjurător, precum și de fenofazele de creștere și tratatamentele aplicate la pomii de păr. În frunzele s. Noiabriscaia, s-a atestat o majorare a activității polifenoloxidazei în toate variantele tratatamentelor: SBA Reglalg - cu 36-81\%; SBA Reglalg + m.e. - cu 31-62\%; microelemente - cu 10-57\%, față de varianta martor, în dependență de fenofazele de creștere.

În rezultatul cercetărilor efectuate s-a constatat, că activitatea enzimelor peroxidaza și polifenoloxidaza s-a modificat pe parcursul ontogenezei în funcție de etapele de dezvoltare a pomilor de păr, particularitățile biologice ale soiurilor cercetate, acțiunea condițiilor de mediu, precum și de substanțele oxidative, care s-au format în celulele plantelor în rezultatul proceselor metabolice sub acțiunea tratamentelor aplicate (SBA Reglalg și m.e). Activitatea scăzută a enzimelor PO și PFO se explică prin rezerva redusă a substratului metabolic, care este utilizat la creșterea și dezvoltarea fructelor (fenofaza de încetinire și încetare a creșterii lăstarilor). Activitatea sporită a enzimelor în frunze se menține într-o legătură constrânsă cu acumularea substanțelor plastice și de rezervă, ce asigură atât funcțiile vitale ale pomilor, cât și menținerea ritmului de desfășurare a proceselor formării și diferențierii mugurilor florali. Activitatea enzimelor în frunze influențează nu numai inducția florală, dar și procesele de reglare a fructificării pomilor. Dinamica modificării activității enzimelor PO și PFO în ontomorfogeneză reflectă metabolismul proceselor de creștere intensivă a pomilor și maturării fructelor.

\section{Concluzii}

- Rolul principal în procesele de oxido-reducere în frunzele pomilor soiurilor de păr cercetate Socrovişce și Noiabriskaia le revine enzimelor antioxidante peroxidaza şi polifenoloxidaza, care îndeplinesc funcții importante în procesele metabolice ale pomilor de păr, îndeosebi în cele de rezistenţă și adaptare la condiţiile nefavorabile ale mediului înconjurător.

- Activitatea peroxidazei și polifenoloxidazei în frunzele soiurilor de păr luate în studiu a depins de particularitățile biologice ale soiului cercetat, tratamentele efectuate (SBA Reglalg și m.e. B, Zn, Mn, Mo), acțiunea condițiilor de mediu, precum și de cantitatea substanțelor oxidative formate în celule ca urmare a proceselor metabolice.

- Aplicarea tratamentelor în perioada de vegetație la pomii de păr contribuie atât la sporirea productivității, cât și la depunerea mugurilor de rod pentru asigurarea roadei în anul următor.

\section{Bibliografie}

1. Sharma P., Jha A. B., Dubei R. S., Ressarakli M. Reactive oxigen species, oxidative damage, andantioxidative defense mechanism in plants understress ful conditions. Jurnal of Botany. 2012. Article ID 217037, 26. p.

2. Șişcanu Gh. Fotosinteza și funcționalitatea sistemului donator-acceptor la plantele pomicole. Chișinău, Tipogr. AȘM. 2018, 316 p.

3. Ştefîrţă A., Aluchi N. ș.a. Antrenarea enzimelor peroxidice în protecția antioxidativă a plantelor în condiții de secetă. Buletinul Academiei de Științe a Moldovei. Științele vieții. 2011, 1 (313), p.50-62.

4. Ştefîrţă A., Brânză L., Vrabie V., Aluchi N. Fiziologia stresului, adaptării și rezistenței la secetă a plantelor de cultură. Chișinău, Tipogr. AȘM. 2017, 372 p.

5. Yoruk R., Marshall M. R. Physicochemical propertiesand function of plant poliphenol oxidase a reviev. J. FOOD Biochem. 2003, v.27. p.361-422. 
6. Воскресенская О. Л., Алябышева Е. А., Половникова М. Г. Большой практикум по биоэкологии. Ч.1. Учебное пособие. Йошкар- Ола, Мар. Гос. Ун-т. 2006, 106 с.

7. Ермаков А. И., Арасимович В. В., Ярош Н. П. и др. Методы биохимического исследования растений. Под ред. Ермакова А. И., 3 изд. Л: Агропромиздат, 1987, 430 с.

8. Кузнецов В. В., Дмитриева Т. А. Физиология растений. М. Высшая школа. 2005, $736 \mathrm{c}$.

9. Меньшикова Е. Б., Зенков Н. К. Антиоксиданты и ингибиторы радикальных окислительных процесов. Успехи современой биологии 1993, 113 (4) с.442-455.

10. Мерзляк М. Н. Активированный кислород и окислительные процессы в мембранах растительной клетки. Итоги науки и техники. Серия Физиология растений.1989.Т.6.167 с.

11. Прадедова Е. В., Ишеева О.Д., Саляев Р. К. Класификация антиоксидантной защиты как основа рациональной организации экспериментального исследования окислительной защиты как основа рациональной организации экспериментального исследования окислительного стресса у растений. Физиология растений 2011, 2 (58). с.177-185. 